\title{
Enterprise resource planning and customer relationship management value
}

Pedro Ruivo (NOVA IMS, Universidade Nova de Lisboa, Lisbon, Portugal)

Tiago Oliveira (NOVA IMS, Universidade Nova de Lisboa, Lisbon, Portugal)

André Mestre (NOVA IMS, Universidade Nova de Lisboa, Lisbon, Portugal)

This is the author accepted manuscript version of the article published by EMERALD as:

Ruivo, P., Oliveira, T., \& Mestre, A. (2017). Enterprise resource planning and customer relationship management value. Industrial Management and Data Systems, 117(8), 1612-1631. https://doi.org/10.1108/IMDS-08-2016-0340

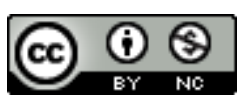

This work is licensed under a Creative Commons Attribution-NonCommercial 4.0 International License. 


\title{
Enterprise Resource Planning and Customer Relationship Management Value
}

\begin{abstract}
Purpose - This paper develops and tests a theoretical model to measure the impact of Enterprise Resource Planning (ERP) and Customer Relationship Management (CRM) systems and moderating relationships of system and process integration on business value.

Design/methodology/approach - ERP and CRM systems are analysed with the Resource-Based View (RBV) theory and measured by their impact on business value, having in consideration the moderation of system and process integration. The model was tested and analysed with data collected by Microsoft, from firms that have adopted both ERP and CRM systems in their organization.

Findings - ERP system is found to be an important asset to business value, but CRM systems' impact on business value is found to be not significant. System integration as moderator of ERP or CRM system is found to be not significant but has a positive and significant impact on business value. For process integration, the study finds that it is significant only when moderating the CRM system variable.

Research limitations/implications - Our model shows that the moderating effects of system and process integration are important variables for understanding the joint business value of ERP and CRM.

Practical implications - Adopting an ERP system and ensuring System integration provides a direct impact on business value. In order for a CRM system to have a positive impact on business value, Process integration with ERP system must be ensured.

Originality/value - This study provides new knowledge on how ERP and CRM systems used together may positively influence value from IT investments, and how systems integration and process integration provide business value.
\end{abstract}

Keywords: ERP; CRM; system integration; process integration; value.

Paper type: Research paper 


\section{Introduction}

Enterprise Resource Planning (ERP) systems have been applied by many firms of varying size around the world as a key part of their organizational architecture. ERP systems support day-today business operations and decision-making processes (Gattiker and Goodhue, 2005, May et al., 2013), and are expected to provide seamless integration of processes across functional areas (Mabert et al., 2003). However, these IT resources streamline and integrate internal business processes to improve efficiency only within a firm's boundaries (Davenport, 1998).

Customer Relationship Management (CRM) systems have exploded on the enterprise space in recent years, and some studies claim that they are the ultimate solution to the information exchange problem among firms (Gartner, 2013, Extraprise, 2008, Chang et al., 2014). CRM extends the original value proposition of ERP, allowing firms to build interactive relationships with their customers and bring together their previously separated information at very low cost (Payne and Frow, 2006, Iriana and Buttle, 2006).

Research states that CRM systems encompass the external part of the extended enterprise, and ERP encompasses the internal part (Gartner, 2013, Extraprise, 2008, Alshawi et al., 2011). That is, while CRM applications extract customer information from customer facing processes, ERP applications leverage the information to configure product offerings, scheduling, and fulfilment processes (Hitt et al., 2002). As more firms realize that they need to know their customers very profoundly in order to compete or survive, integrating CRM with ERP becomes a critical topic (Payne and Frow, 2005, Ryals, 2005). Integrated CRM and ERP systems automatically communicate customer and process-related information to each other (Rai et al., 2006), increase interdepartmental connectedness, facilitate the dissemination of market intelligence amongst multiple departments and locations, and improve the entire organization's responsiveness to consumer demands (Liu et al., 2013).

Moreover, some researchers suggest that IT value is better captured when taking into consideration moderator relationships on the link between IT resources and business value (Liu et al., 2013, Mishra and Agarwal, 2010). Although few, some IS researchers have identified ERP and CRM integration as one of the most important fields for future IT value research (King and Burgess, 2008, Alshawi et al., 2011, Davenport, 1998, Kim et al., 2015, Willis and WillisBrown, 2002, Liu et al., 2013, Melville et al., 2004) and claim that system integration is a key factor that shapes how IT is applied to digitize business processes and generate value. Some researchers point out that business process integration plays an important role for return on investment on improvements in both ERP (Roh and Hong, 2015, Narayanan et al., 2011, 
Samaranayake, 2009) and CRM (Osarenkhoe and Bennani, 2007, Light, 2003, Nguyen and Mutum, 2012, Liu et al., 2013).

Motivated by these issues, this study develops and tests a theoretical model grounded in a wellestablished IS theory, Resource-Based View (RBV). We investigate the impact of the joint ERP and CRM systems value by taking into consideration the moderating relationships of system and process integration. In doing so, we contribute to the IT value literature by examining the complementarity value of the integration of these two resources. Our work focuses on answering the following research questions (RQs):

RQ1 - Are ERP and CRM systems drivers of business value?

RQ2 - Are systems and processes integration drivers of business value?

RQ3 - Do systems and processes integration work as moderators of ERP and CRM systems in business value creation?

The remainder of the paper is organized as follows. In Section 2 we provide a literature review on ERP and CRM business value, followed by an overview of RBV theory of the firm that underpins our research model. In Section 3 we present the proposed research model and hypotheses. In Section 4 we explain the research methodology and operationalize the variables. Section 5 has the results and analysis. In Section 6 we discuss the results, present the managerial implications, contributions, limitations, and directions for future work. In the last section we present the concluding remarks.

\section{Literature review}

The purpose of this section is to position our literature review with regard to existing knowledge about the ERP and CRM value. More precisely, we first review the three streams of published studies that build our knowledge: (1) The ERP business value, (2) the CRM business value, and (3) the role of systems and process integration on business value. Then we set the RBV theory of the firm as the theoretical framework for linking the ERP and CRM to business value.

\subsection{The ERP business value}

In reviewing ERP studies we were able to find seven literature review publications: Esteves and Pastor (2001) analysed 189 papers, Shehab et al. (2004) analysed 76, Botta-Genoulaz et al. (2005) analysed 80, Cumbie et al. (2005) analysed 49, Esteves and Bohorquez (2007) analysed 640, Schlichter and Kraemmergaard (2010) analysed 885, and Huang and Yasuda (2016) analysed 86 papers. These studies reveal the rich variety and practice of ERP systems in 
different firms. Still, the authors claim that ERP research is lacking studies addressing the ERP business value. In this line, our review of earlier research that is focused on the relationship of ERP with business value reveals three main clusters of studies:

1) the first investigates tangible areas of ERP in firms' performance, basically following the "IT productivity paradox" paradigm (Dedrick et al., 2003). Traditional cost measures such as direct operating costs (ROA, ROE, COGS, SG\&A, profit margin) (Nicolaou and Bhattacharya, 2006, Nicolaou and Bhattacharya, 2008, Nicolaou, 2004), inventory levels, and cash management (Hitt et al., 2002, Aral et al., 2005) are used;

2) the second reports that most of the business value in ERP use resides in intangible areas such as increased interactions across the enterprise, quick response time for information, availability and quality of information (Ranganathan and Brown, 2006, Mabert et al., 2003), improvements in communications, user satisfaction, and management control (Rhodes et al., 2009, Gattiker and Goodhue, 2005, Zhang et al., 2005, Bradford and Florin, 2003), improvements in coordination between different units, cost efficiency, and differentiation (Hitt et al., 2002, Nicolaou and Bhattacharya, 2006, Al-Mashari, 2002), efficiency, enhanced process integration, automation, and optimization (Roh and Hong, 2015, Narayanan et al., 2011, Samaranayake, 2009, Finney and Corbett, 2007);

3) a third cluster addresses tangible and intangible complementarity measures and investigates a positive relationship between ERP and business value (Ruivo et al., 2012, Ruivo et al., 2015, May et al., 2013, Willis and Willis-Brown, 2002).

However, according to several authors (Huang and Yasuda, 2016, Ram et al., 2014, Ruivo et al., 2012, Nicolaou and Bhattacharya, 2006, Velcu, 2007) ERP would have a better impact on business value when complementing other IT resources. These findings resonate with earlier work by Laframboise and Reyes (2005) and Holland et al. (2001), who suggest that ERP may not be sufficient by itself to have a great impact on business value, but can provide the platform on which other resources can excel and thereby create a unique system that greatly boosts business value.

\subsection{The CRM business value}

In reviewing CRM studies we were able to find six literature review publications: Romano and Fjermestad (2003) analysed 369 articles, Ngai (2005) analysed 205 papers, Paulissen et al. (2007) analysed 510 papers, Ngai et al. (2009) analysed 87 papers, Wahlberg et al. (2009) analysed 468, and Soltani and Navimipour (2016) analysed 27 papers. These studies reveal the rich variety and practice of CRM systems in different firms, but the authors claim that CRM research is lacking studies addressing the CRM business value. In this line, our review of earlier research that is focused on the relationship of CRM with business value reveals three main clusters of studies: 
1) the first assesses the CRM value through tangible measures such as the success at generating revenues from new products, reduction in cost of transacting with customers, level of repeat purchase (Payne and Frow, 2005, Payne and Frow, 2006, Iriana and Buttle, 2006, Dong and Zhu, 2008, Alshawi et al., 2011), and increase in return on assets, return on sales, and return on equity (Boulding et al., 2005, Hillebrand et al., 2011, Reinartz et al., 2004);

2) in the second cluster CRM creates intangible value for both the firm and its customers through the appropriate system's usage, data, and customer knowledge (Alshawi et al., 2011, Chen and Popovich, 2003, Payne and Frow, 2006). It brings together people, processes, technology, and organizational capabilities to ensure connectivity between the company, its customers, and collaborating firms (Light, 2003, Liu et al., 2013, Nguyen and Mutum, 2012, Osarenkhoe and Bennani, 2007);

3) a third cluster assessing both tangible and intangible measures reports efficiency gains in the front-office process (Albert et al., 2004, Jayachandran et al., 2005, Karimi et al., 2001, Minami and Dawson, 2008, Chang et al., 2014, Kim et al., 2015), and improved customer information in the back-office process (Ernst et al., 2011, Mithas et al., 2005, Padmanabhan et al., 2006, Liu et al., 2013, Bull, 2003, Pedron et al., 2016).

However, several researchers have expressed concerns about the lack of research on the combination of IT resources such as CRM with ERP systems that deliver most business value (Mithas et al., 2011, Aral et al., 2005, Aral and Weill, 2007, Liu et al., 2013, Alshawi et al., 2011, Chen and Popovich, 2003, Hendricks et al., 2007).

\subsection{The role of systems and process integration on business value}

According to several researchers (Rai et al., 2006, Hsu, 2013b, Barki and Pinsonneault, 2005, Ranganathan and Brown, 2006), the benefits of IT integration of business applications such as ERP and CRM can be attained on two levels: systems integration and process integration.

Systems integration refers to the degree of linkages between different computer-based information systems and databases. It is the process of linking together different software applications such as the ERP and CRM to work in a coordinated manner (Melville et al., 2004, Liu et al., 2013, Francalanci and Morabito, 2008). The business value of systems integration is data quality and data integration. Firms can work more intelligently with data because it eliminates double data entry, increases data accuracy, and data become visible across the firm (Ram et al., 2013, Hsu, 2013b, Bharadwaj et al., 2007, Laframboise and Reyes, 2005).

Process integration represents the extent to which the business processes of two departments are tightly coordinated and standardized through the firm's information system (Barki and Pinsonneault, 2005, Chen and Popovich, 2003, Francalanci and Morabito, 2008). The business value of ERP and CRM process integration is that integrated myriad business processes save time and expense. Firms can then make decisions more quickly with fewer errors and greater 
insights (Samaranayake, 2009, Narayanan et al., 2011); more precisely, automate common business processes such as contact and account integration, product integration, order and quote management, and order/invoice tracking (Roh and Hong, 2015, Nguyen and Mutum, 2012, Osarenkhoe and Bennani, 2007).

Systems integration is a prerequisite and facilitator of business process integration. However, two departments or subsidiaries might both achieve a high level of system integration, but their process integration level might vary due to a reluctance to share information (Chen and Popovich, 2003, Hsu, 2013b, Rai et al., 2006). Literature suggests that it is only when system and process integration are measured in conjunction with a firm's IT resources that these will have a positive impact on business value (Rai et al., 2006, Ranganathan and Brown, 2006, Dong and Zhu, 2008, Boulding et al., 2005, Hendricks et al., 2007, Hsu, 2013b).

\subsection{The RBV and business value}

A potential framework for extending the theoretical basis of IT value is the Resource-Based View (RBV) of the firm, which is rooted in economics and management rationales (Melville et al., 2004). When the firm resources are valuable, non-imitable, and non-substitutable, they can explain the differences in business value (Rhodes et al., 2009, Zhu and Kraemer, 2005). The RBV has been used in the IS literature to explain IT business value, in which firm-specific sets of resources determine the firm's performance (Zhu and Kraemer, 2005, Uwizeyemungu and Raymond, 2012, Ruivo et al., 2012, Ruivo et al., 2015). Some researchers have emphasized that an IT resource, such as ERP, is likely to affect business value only when it is deployed to create unique integrative complementarities with other IT resources, such as CRM systems (Rai et al., 2006, Wade and Hulland, 2004). Integrative complementarity represents the enhancement of resource value, because a resource produces greater returns when integrated with another resource, than by itself (Wade and Hulland, 2004, Melville et al., 2004, King and Burgess, 2008).

Although business components such as ERP and CRM systems that go into the firm's infrastructure are commodities-like, the process of integrating these components makes a firmspecific system difficult to be substituted and understood by competitors (Bharadwaj, 2000, Zhu and Kraemer, 2005, King and Burgess, 2008).

Upon review of earlier research streams, we conclude that while the reported studies have expanded the business value of ERP and CRM understanding, the results look at these systems only separately. No study was found that assesses the joint value of ERP and CRM grounded in the RBV theory. The present study uses the RBV as a frame of reference to develop a theoretical model to understand the extent to which ERP and CRM integration contributes to business value. We next define the model variables and hypotheses. 


\section{Research model and hypotheses}

Focusing on the process-oriented view about the business value creation of IT (Zhu and Kraemer, 2005, Picoto et al., 2014), we advance the above stream and develop a research model to understand the impact of ERP and CRM systems moderated by system and process integration on business value. Our research model is illustrated in Figure 1.

$<$ Insert Figure 1 here $>$

We theorize that "Business value" is driven by four antecedent variables: ERP system, CRM systems, system integration, and process integration, and that it is moderated by two variables: system integration and process integration. These variables are hypothesized to measure the impact of ERP and CRM integration on business value. Business value is a second-order variable of three dimensions: impact on operations, impact on procurement, and impact on sales, which are grounded in the value chain analysis that has been broadly used in the IS literature to study the business value of IT (Zhu and Kraemer, 2005, Picoto et al., 2014). We next present the hypotheses of the model.

\subsection{Hypotheses for direct relationships}

Taking into consideration the theoretical background presented above, whereas ERP systems focus on internal process and are expected to affect a firm's internal operations by decreasing internal costs (Gattiker and Goodhue, 2005), CRM systems focus on external, intra-firm process efficiency and effectiveness by decreasing coordination costs and reaping the benefits of customer relationships (Goodhue et al., 2002). In this line we postulate the following:

H1: Firms with greater ERP system functionality are more likely to generate higher business value.

H2: Firms with greater CRM system functionality are more likely to generate higher business value.

Integrating ERP and CRM might be a technically complex process. An ERP system generally embodies firm's business logic, in which the routines, rules, and procedures such as procurement, fulfilment, and approvals are made over electronic transactions that are expanded and enhanced when technically tied with other systems (Hsu, 2013b, Gattiker and Goodhue, 2005). CRM functions must generally adapt to the business logic, and therefore a successful integration between ERP and CRM systems is considered to be valuable, heterogeneously 
distributed, difficult to be imitated, and difficult to be substituted, which is in accordance with RBV rationales (Gattiker and Goodhue, 2005, Goodhue et al., 2002, Liu et al., 2013). In this line we postulate the following:

H3a: Firms with greater system integration are more likely to generate higher business value.

H4a: Firms with greater process integration are more likely to generate higher business value.

\subsection{Hypotheses for moderator relationships}

Several earlier studies consider that moderating relationships best explain the IT integration value (Liu et al., 2013, Melville et al., 2004, Boulding et al., 2005). In addition to incorporating whether ERP and CRM are integrated into the entire value chain (as proxy) we also consider that there are two moderators that will reinforce the positive relationship between ERP and CRM systems and the business value of the firm's information system: system integration and process integration. Whereas system integration is the IT component that creates the correct links between different information systems and databases, process integration is the extent to which the business processes of the two systems are tightly linked and standardized into what could be described as a single information system. Given that ERP and CRM are strategic initiatives that involve both business and IT, their impact on a business value should also be examined in the systems and business process settings in which the firm operates specifically, because it is a richer field in which to build competitive advantages, which is consistent with RBV rationales. Hence, we postulate the following four hypotheses:

H3b: System integration moderates the relationships of ERP system on business value, such that it is stronger amongst the firms with high system integration level.

H3c: System integration moderates the relationships of CRM system on business value, such that it is stronger amongst the firms with high system integration level.

H4b: Process integration moderates the relationships of ERP system on business value, such that it is stronger amongst the firms with high process integration level.

H4c: Process integration moderates the relationships of CRM system on business value, such that it is stronger amongst the firms with high process integration level.

\section{Research methodology}

To test our research model a survey instrument was designed to collect data on each of the variables in the model. 


\subsection{Data}

In accordance with Zhu and Kraemer (2005), theory development usually progresses to empirical testing, and hence a questionnaire was designed to investigate the ERP and CRM business value (see Appendix). A web-based survey was developed from the literature by choosing appropriate items. A group of five established academic researchers reviewed the instrument for content validity (Venkatesh et al., 2012). The initial questionnaire was pilot tested in 50 firms, randomly selected from Microsoft database using both ERP and CRM systems, in Lisbon area (15) and Madrid area (35), to assess any item's difficulty or ambiguity and to test the reliability and validity of the scales. The 30 firms that responded (11 from Lisbon and 19 from Madrid) were contacted for a telephone interview to ask for their opinions on the questionnaire and to identify any items that they found to be confusing or ambiguous. Some items were revised for clarity. This phase provided preliminary evidence on the reliability and validity of the scales.

In accordance with Hwang (2005), a socio-technical approach of enterprise systems involves the integration of business process and technical aspects such as systems integration to overcome uncertainty. Moreover, Hofstede's (2001) cultural dimensions study concluded that Portugal and Spain (composing the Iberian region) are the countries with the highest uncertainty avoidance rate. We therefore selected these two countries as a proxy (Leidner and Kayworth, 2006). It should be noted that the goal of studying these two countries was to understand the relationships of the proposed model. Careful attention was given to ensure the validity and reliability of the findings. That is, the sample was carefully and systematically identified; primary data were used; pilot-test was developed prior to the web-survey; data were stratified by industry area and firm size, and collected and stored in a systematic manner; and the results were revised, verified, and analysed with advanced statistics (Zhu and Kraemer, 2005). Our future research will be to test the model for firms in different areas and from different countries.

Firms eligible for inclusion in the study were selected from Microsoft database. After filtering by country (Portugal and Spain) and using both ERP and CRM systems in their daily business activities, we obtained a final list with 400 firms. 150 firms from Portugal and 250 from Spain received the web-survey in September 2015 from Microsoft. In order to increase content validity and response rate, we indicated that the respondents should be individuals with ERP and CRM knowledge within the firms, and we offered to share the results of the research to improve the response rate and increase content validity. To the non-respondents a follow up email was sent three weeks after the first e-mail. 125 valid responses were returned (93 early and 32 later), resulting in a response rate of $31.25 \%$. To test non-response bias we compared early and late respondents groups based on the Kolmogorov-Smirnov (K-S) test and found no 
statistically significant differences between the two groups (Ryans, 1974). We used Harman's one-factor test (Podsakoff et al., 2003) to examine the common method bias, showing that the first factor explains $37.6 \%$ of the variance. This means that none of the factors explain the majority of the variance. To ensure the generalization of the survey results, the sampling was stratified by firm size, by industry type (financial services, retail, manufacturing, professionalservices, information technology, and utilities), and by ERP and CRM system's vendor. Table 1 shows the characteristics of the sample and of the respondents, such as industry and role, which indicate that they were qualified to speak about the firm's ERP and CRM value, suggesting the good quality of the data.

$<$ Insert Table 1 here $>$

\subsection{Operationalization of the variables}

The variables and measurement items were adapted from previously validated measures or developed on the basis of the literature review discussed in the previous section. Respondents were asked to rate their perceptions. The variables were measured on a five-point quantitative scale, in which 1 means "low" and 5 "high".

The ERP system variable is operationalized as the extent to which ERP is being used to conduct the firm's value-chain based activities. It refers to the scope of ERP system modules a firm uses in daily business activities. The way we measure this variable is similar to that in earlier studies (Ranganathan and Brown, 2006). More precisely, this variable was measured through three item-questions that assess the extent to which a firm uses ERP financial module, supply chain module, and manufacturing module.

The CRM system variable is operationalized as the extent to which CRM is being used to conduct the firm's customer-oriented based activities. It refers to the scope of CRM system modules a firm uses in daily business activities. The way we measure this variable is similar to that in earlier studies (Payne and Frow, 2005). More precisely, this variable was measured through three item-questions that assess the extent to which firms use CRM marketing module, sales module, and service module.

The System integration variable is operationalized as the extent to which different information systems are interconnected and can communicate with one another. It refers to the extent to which information systems are technically integrated along the value-chain and customeroriented based activities. The way we measure this variable is similar to that in earlier studies (Barki and Pinsonneault, 2005). More precisely, this variable was measured through three item- 
questions that assess the extent to which a firm's ERP system is integrated with the firm's CRM system and business partner's IS, and by the extent to which the firm's CRM is accessible by the firm's business partners via web or other electronic networks.

The Process integration variable is operationalized as the extent to which operational information is shared between the firm's departments or locations. It refers to the extent to which decision making processes are based on real-time information throughout the value-chain and customer-oriented based activities. The way we measure this variable is similar to that in earlier studies (Rai et al., 2006). More precisely, this variable was measured through three itemquestions that assess the extent to which a firm shares inventory levels and product information across departments or locations, and shares demand and forecasting information across departments or locations.

The Business value variable is operationalized as a second-order construct manifested by three business value dimensions, as defined with regard to the arguments made above. The way we measure this variable is similar to that in earlier studies, whereby such a second-order approach represents a theoretically strong basis for capturing complex measures (Zhu and Kraemer, 2005). More precisely, this variable was measured through six item-questions grouped into three dimensions that assess the impact on internal operations (decreased internal operations costs and improved on-time delivery), impact on procurement (decreased inventory and procurement costs), and impact on sales (improved sales, and customer service and support).

\subsection{Control variables}

Earlier studies suggest that ancillary factors can influence ERP and CRM business value. Firm size is used as a proxy for the resource base of the organization that may influence the firm's integrative information systems value and business value (Elbashir et al., 2013). Time since both systems were integrated was included to measure the knowledge and experience that organizations obtain from working over time (Elbashir et al., 2013). IT related infrastructure sophistication assesses the differences in both generic and specialized systems that may affect the integrative value and also performance (Elbashir et al., 2013). Hence, we use three controls: firm size, time since integration, and IT infrastructure sophistication. 


\section{Results and analyses}

In the next two sub-sections we analyse the instrument validation (measurement model and the structural model). As none of the items in our data are normally distributed $(p<0.01$ based on the Kolmogorov-Smirnov test), the partial least squares (PLS) is the appropriate method to use to estimate the research model (Chin, 1998, Henseler et al., 2009). We used SmartPLS 2.0 (Ringle et al., 2005) software to analyse the models.

\subsection{Measurement model}

In our model we have reflective constructs. In the context of PLS the measurement model for the reflective constructs should be evaluated based on indicator reliability, construct reliability, convergent validity, and discriminant validity (Henseler et al., 2009). 1) The indicator reliability is the absolute standardized loadings. This indicator was evaluated based on the criteria that the loadings should be greater than 0.7 and that every loading less than 0.4 should be eliminated (Henseler et al., 2009, Chin, 1998). The items are reported in Table 2, where it is seen that the loadings are greater than 0.7 , with the exception of two (CRM2 and ERP1), which are lower than 0.7 but greater than 0.4 . Hence, no items in the table were eliminated. All the items are statistically significant at 0.001 . Overall, the instrument presents good indicator reliability. 2) Construct reliability was measured based on the composite reliability (CR) and values higher than 0.7 can be regarded as satisfactory. Table 2 shows that the $\mathrm{CR}$ for each variable is above the cut-off of 0.7 (Chin, 1998, Henseler et al., 2009). 3) Average variance extracted (AVE) was used as the criterion to test convergent validity. The AVE should be higher than 0.5 , so that the latent variable explains more than half of the variance of its indicators (Henseler et al., 2009, Fornell and Larcker, 1981, Hair et al., 2012). Table 2 shows that the AVE for each variable is above the cut-off of 0.5 (Chin, 1998).

$<$ Insert Table 2 here $>$

4) Discriminant validity is the extent to which a construct is truly distinct from other constructs by empirical standards. Thus, establishing discriminant validity implies that a construct is unique and captures phenomena not represented by other constructs in the model (Hair et al., 2012). Discriminant validity of the variables was assessed using two criteria; the FornellLarcker (1981) criterion and cross-loadings. For the first criterion we compute the square root of AVE (Table 3 in bold) for constructs that are greater than the correlation between each pair of constructs (off-diagonal elements), except with regard to the correlations involving the construct "business value", and the three constructs contributing to it (impact on operations, impact on 
$<$ Insert Table 3 here $>$

procurement, and impact on sales). This was to be expected since "business value" corresponds to a second-order construct of "impact on operations", "impact on procurement", and "impact on sales". The second criterion ensures that the loadings of each indicator are greater than all cross-loadings (Chin, 1998). The Table with loadings and cross-loadings is available from the authors on request.

Our model has good indicator reliability, construct reliability, convergent validity, and discriminant validity. Thus, variables developed using this measurement model can be used to assess the structural model.

\subsection{Structural model and hypothesis testing}

The structural model was assessed by examining the $\mathrm{R}^{2}$ and the level of significance of the path coefficients. The research model explains $58.7 \%$ of the business value variation, which is considered substantial (Chin, 1998). Therefore, we believe that the variables model significantly explains data variations for integrative value and its underlying business value dimensions. The significance of the path coefficients was derived from bootstrapping (5000 resamples) (Chin, 1998). Figure 2 shows the model results and path coefficients.

$<$ Insert Figure 2 here $>$

Figure 2 shows that ERP systems have a positive and significant impact on business value $\left(0.260^{* * *}\right)$ and CRM system shows a positive impact but is not statistically significant (0.023). Therefore, only H1 is supported. System integration has a positive and significant impact on business value $\left(0.346^{* * *}\right)$ and process integration shows a positive impact but is not statistically significant (0.173). Hence, only H3a is supported.

The moderation effect of system integration on both ERP system and CRM system are not statistically significant, and hence $\mathrm{H} 3 \mathrm{~b}$ and $\mathrm{H} 3 \mathrm{c}$ are not supported. Although the moderation effect of process integration shows a positive and significant effect on CRM system (0.196*), it is not statistically significant on ERP system (0.029). As a result, only H4b is supported.

In short, H1 (ERP system), H3a (system integration), and H4b (the process integration moderator of the CRM systems on business value) are supported. H2 (CRM system), H3b (the system integration moderator of the ERP system on business value), H3c (the system integration 
moderator of the CRM system on business value), H4a (process integration), and $\mathrm{H} 4 \mathrm{c}$ (the process integration moderator of the CRM system on business value) are not supported.

\section{Discussion}

The empirical results demonstrate two major findings: i) ERP systems by themselves are still considered an important asset to business value, while CRM systems' impact on business value is shown to be not significant, even if positive; and ii) system integration as moderator of ERP or CRM system is shown to be not significant but has a positive and significant impact on business value. For process integration, we conclude that it is significant only when moderating the CRM system variable.

Our results show that ERP systems, even if considered as standardized and a commodity in earlier literature (Hsu, 2013a), are still found to be valuable to companies and key contributors to business value. ERP systems support critical parts of firms' value chains, operations, procurement, and sales processes, and therefore have a great impact on business value. Earlier IT and ERP literature (Hsu, 2013b, May et al., 2013) also indicates that the mere adoption of these kinds of systems does not guarantee business value gains, and at the same time RBV says that a resource is more likely to generate value when not widely used (Hsu, 2013a), which is the case of ERP systems (usage for several years and dependence on software vendors for configuration and functionalities). Nevertheless, we have concluded that ERP systems are critical and encompass core processes of companies to the point that, where correctly implemented, they may have specificities to each firm that are difficult to imitate and contribute to competitive advantage and business value.

On the other hand, CRM system shows positive but non-significant impact on business value. Enterprise softwares such as CRM systems, as delivered by software vendors, contain out-ofthe-box functionalities that are widely used without the need for configuration or customization (Ruivo et al., 2015). According to RBV, these can be seen as easy to imitate and therefore less important for competitive advantage or business value, which falls into line with our findings. The moderator effect of process integration shows that CRM systems can become more impactful on business value when well integrated with firms' business processes (Chang et al., 2014). While in this study we could not conclude that CRM system is core in business value creation, CRM should always be seen as a business strategy that affects technology, but also people, and more importantly business processes. 
System and processes integration are two firm-specific capabilities that, according to RVB, can affect business value (Hsu, 2013b) since technology can be easily imitated but not the knowledge and transformation needed to integrate systems and streamline business processes. Our results show that the system integration moderation effect in both ERP and CRM systems is not significant, but nevertheless proved to be significant to business value. One conclusion we can take from this result is that there might be other systems besides ERP and CRM contributing to business value, such as e-commerce systems, internal line of business applications, partner and supplier systems, etc.

Process integration, on the other hand, is not significantly affecting business value, but has a positive and significant contribution in the moderation of the CRM system variable. Therefore, and in line with literature (Liu et al., 2013, Alshawi et al., 2011), CRM is a business strategy that affects technology, people, and also business processes, and our results show that CRM system will in fact have a greater impact on business value when deeply integrated into firms' business processes.

\subsection{Managerial implication}

We make four fundamental managerial recommendations with this study: i) Firstly, the results imply that firms can create business value by developing a joint software system consisting of ERP and CRM. More precisely, results show that firms with greater levels of system integration are generating higher business value. This implies that managers should define as a strategy the integration of disconnected systems such as CRM and ERP to achieve higher value. This points to the importance of moving beyond individual systems value creation. ii) Secondly, our results showing the significant value implication of ERP on business value but not significant for CRM, imply that ERP systems per se create higher business value even when coupled with a CRM system. This implies that managers should first focus on making sure that the firm's ERP systems are well implemented and configured and then couple CRM and other systems. In doing this, the value of ERP is amplified (Hsu, 2013b, Pedron et al., 2016). iii) Thirdly, our results show that when CRM and ERP are simply technically integrated, CRM does not create high business value. CRM creates greater business value when processes are integrated with ERP and other systems. This points to the importance of broader IT system integration when coupling systems. Instead of accumulating functional modules within a software system and having the systems technically integrated, both IT and functional managers need to take into consideration processes integration between systems. Managers should blur the lines between CRM and ERP systems by also pushing ERP information to the frontline CRM, shifting from unidirectional to bidirectional data-flow between systems. If firm's sales, service, and other frontline departments have fingertip access to select ERP information in their CRM system, they 
can immediately address customer questions about product availability or review the status of credit checks for new customers without wasting time emailing or chasing their finance team. iv) Lastly, CRM vendors should pay attention to developing their applications to create higher value in accordance with business process integration, for example, social networks and sentiment analysis systems as part of CRM process integration. This may help increase the value of customer's CRM systems, the joint value of CRM and ERP, and the market value of vendor's products.

\subsection{Contributions to theory}

This study extends the literature in four ways: i) we include the integration of CRM and ERP applications in the analysis of value creation, ii) we include system and processes integration to explain business value, iii) we investigate how system and process integration moderates the ERP and CRM system to explain business value, and iv) we examine the link between information system value and business value. There is earlier literature and theory around the value created by ERP and CRM systems but it is very limited when it comes to addressing the importance and benefits of using ERP and CRM systems integrated and as important contributors to business value. As our model was based on the RBV theory, we also addressed the moderating effect of system and process integration, since these are two very specific firm capabilities that may create competitive advantage and also contribute to business value.

\subsection{Limitations and future work}

One of the limitations of our research has to do with the sample size and variety. We targeted 400 firms in Portugal and Spain with the questionnaire and received 125 valid responses. Future work will be to assess the model's variables relationships with a larger sample by, for example, expanding it to other countries and comparing the results. With this study we have not made any industry-specific analysis, even though we analysed the industries of the respondents. The use of ERP and CRM systems and also their integration with systems and processes might differ from one industry to another, as for example in the modules of ERP and CRM typically used. Our results show that CRM system is still not seen as critical to business value. According to literature (Liu et al., 2013), CRM systems are proved to be adopted by companies in markets in which products are more differentiated or in which entry costs are lower, and that at the same time it should be seen as a business strategy that affects not only technology but also people and processes (Liu et al., 2013, Alshawi et al., 2011, Chang et al., 2014). This means that our sample and analysis might have been affected by i) the role of the person responding (we had $c a .25 \%$ IT/IS Managers), and/or ii) the market, strategy, or type of business of the companies targeted. Future work might compare, for example, the results from IT related roles with business roles. 


\section{Concluding remarks}

Our work focused on measuring the impact of ERP and CRM systems, as well as the moderating effect of system and process integration on business value. For that, we developed a research model based on RBV theory. To test the proposed model, data were collected by Microsoft. 125 valid responses from the Iberian Region (Portugal and Spain) were used to test the conceptual model. According to the results and their significance, we propose that companies continue to implement ERP systems in order to create business value but at the same time not neglect the importance that the integration between those ERP systems and the broader IT infrastructure might bring to their business value. Our results show that ERP systems still have a direct impact on business value by themselves, so they should be kept as a priority to companies. Moreover, firms should take into consideration the integration between business processes and CRM systems, as this will definitely impact the business value extracted from these systems. CRM systems need to be part of a broad set of business processes and not just another software package in which data are stored but without effect on business processes or decision-making. We find our study to be unique in the way we approach the integration between ERP and CRM systems as drivers of business value, and also in the way we bring System and Process Integration to moderate the two IT resource variables. We also hope that this study and the model we developed and tested can contribute to further research in this area, for example by extending it to other systems such as e-business and supply chain management systems.

\section{References}

AL-MASHARI, M. 2002. Enterprise resource planning (ERP) systems: a research agenda. Industrial Management \& Data Systems, 102, 165-170.

ALBERT, T. C., GOES, P. B. \& GUPTA, A. 2004. GIST: a model for design and management of content and interactivity of customer-centric web sites. MIS Quarterly, 161-182.

ALSHAWI, S., MISSI, F. \& IRANI, Z. 2011. Organisational, technical and data quality factors in CRM adoption - SMEs perspective. Industrial Marketing Management, 40, 376-383.

ARAL, S., BRYNJOLFSSON, E. \& WU, D. J. 2005. Does process IT matter? Measuring the buiness value of extended enterprise systems. In: WISE (ed.) Workshop on Information Systems and Economics. University of California.

ARAL, S. \& WEILL, P. 2007. IT Assets, Organisational Capabilities and Firm Performance: How Resource Allocations and Organisational Differences Explain Performance Variation. Organization Science, 18, 1-18.

BARKI, H. \& PINSONNEAULT, A. 2005. A model of organizational integration, implementation effort, and performance. Organization Science, 16, 165-179.

BHARADWAJ, A. S. 2000. A resource-based perspective on information technology capability and firm performance: an empirical investigation. MIS Quarterly, 24, 169-197.

BHARADWAJ, S., BHARADWAJ, A. \& BENDOLY, E. 2007. The performance effects of complementarities between information systems, marketing, manufacturing, and supply chain processes. Information Systems Research, 18, 437-453.

BOTTA-GENOUlAZ, V., MILlET, P. A. \& GRABOT, B. 2005. A survey on the recent research literature on ERP systems. Conmputers in Industry, 56, 510-522.

BOULDING, W., STAELIN, R., EHRET, M. \& JOHNSTON, W. J. 2005. A customer relationship 
management roadmap: what is known, potential pitfalls, and where to go. Journal of Marketing, 69, 155-166.

BRADFORD, M. \& FLORIN, J. 2003. Examining the role of innovation diffusion factors on the implementation success of enterprise resource planning systems. International Journal of Accounting Information Systems, 4, 205-225.

BULL, C. 2003. Strategic issues in customer relationship management (CRM) implementation. Business Process Management Journal, 9, 592-602.

CHANG, H. H., WONG, K. H. \& FANG, P. W. 2014. The effects of customer relationship management relational information processes on customer-based performance. Decision Support Systems, 66, 146159.

CHEN, I. J. \& POPOVICH, K. 2003. Understanding customer relationship management (CRM): People, process and technology. Business Process Management Journal, 9, 672-688.

CHIN, W. W. 1998. Issues and opinion on stuctural equation modeling. MIS Quarterly, 22, 7-16.

CUMBIE, B. A., JOURDAN, Z., PEACHEY, T., DUGO, T. M. \& CRAIGHEAD, C. W. 2005. Enterprise resource planning research: where are we now and where should we go from here? JITTA: Journal of Information Technology Theory and Application, 7, 21.

DAVENPORT, T. H. 1998. Putting the enterprise into the enterprise system. Harvard Business Journal, 76, 121-131.

DEDRICK, J., GURBAXANI, V. \& KRAEMER, K. L. 2003. Information technology and economic performance: a critical review of the empirical evidence. ACM Computing Surveys, 35, 1-28.

DONG, S. \& ZHU, K. The Business Value of CRM Systems: A Resource-Based Perspective. 41st Annual Hawaii International Conference on System Sciences, 2008. 277.

ElbASHIR, M. Z., COllier, P. A., SUTTON, S. G., DAVERN, M. J. \& LEECH, S. A. 2013. Enhancing the Business Value of Business Intelligence: The Role of Shared Knowledge and Assimilation. Journal of Information Systems 27, 87-105.

ERNST, H., HOYER, W. D., KRAFFT, M. \& KRIEGER, K. 2011. Customer relationship management and company performance - the mediating role of new product performance. Journal of the Academy of Marketing Science, 39, 290-306.

ESTEVES, J. \& BOHÓRQUEZ, V. W. 2007. An updated ERP systems annotated bibliography: 20012005. Instituto de Empresa Business School Working Paper No. WP, 07-04.

ESTEVES, J. \& PASTOR, J. 2001. Enterprise resource planning systems research on ERP systems research: an annotaded bibliography. Connunications of the Association for Information Systems, 7.

EXTRAPRISE. 2008. CRM Support Survey Report. Available: http://www.meritalk.com/uploads_legacy/whitepapers/Extraprise_CRM_Support_Survey_Report.pdf.

FINNEY, S. \& CORBETT, M. 2007. ERP implementation: a compilation and analysis of critical success factors. Business Process Management Journal, 13, 329-347.

FORNELL, C. \& LARCKER, D. F. 1981. Evaluating Structural Equation Models with Unobservable Variables and Measurement Error. Journal of Marketing Research (JMR), 18, 39-50.

FRANCALANCI, C. \& MORABITO, V. 2008. IS Integration and Business Performance: The Mediation Effect of Organizational Absorptive Capacity in SMEs. Journal of Information Technology, 23, 297314.

GARTNER. 2013. Hype Cycles 2013. Available: http://www.gartner.com/technology/research/hypecycles/.

GATTIKER, T. F. \& GOODHUE, D. L. 2005. What happens after ERP implementation: understanding the impact of inter-dependence and differentiation on plant-level outcomes. MIS Quarterly, 29, 559585.

GOODHUE, D. L., WIXOM, B. H. \& WATSON, H. J. 2002. Realizing business benefits through CRM: hitting the right target in the right way. MIS Quarterly Executive, 1, 79-94.

HAIR, J., SARSTEDT, M., RINGLE, C. \& MENA, J. 2012. An assessment of the use of partial least squares structural equation modeling in marketing research. Journal of the Academy of Marketing Science, 40, 414-433.

HENDRICKS, K. B., SINGHAL, V. R. \& STRATMAN, J. K. 2007. The impact of enterprise systems on corporate performance: a study of ERP, SCM, and CRM system implementations. Journal of Operations Management, 25.

HENSELER, J., RINGLE, C. M. \& SINKOVICS, R. R. 2009. The use of partial least squares path modeling in international marketing. Advances in international marketing, 20, 277-319.

HILLEBRAND, B., NIJHOLT, J. J. \& NIJSSEN, E. J. 2011. Exploring CRM effectiveness: an institutional theory perspective. Journal of the Academy of Marketing Science, 39, 592-608.

HITT, L. M., WU, D. J. \& ZHOU, X. 2002. Investment in enterprise resource planning: business impact and productivity measures. Journal of Management Information Systems, 19, 71-98. 
HOFSTEDE, G. 2001. Culture's Consequences: Comparing values, behaviors, institutions, and organizations across nations, Sage Publications.

HOLLAND, C. P. \& LIGHT, B. 2001. A stage maturity model for enterprise resource planning systems use. SIGMIS Database, 32, 34-45.

HSU, P.-F. 2013a. Commodity or competitive advantage? Analysis of the ERP value paradox. Electronic Commerce Research and Applications, 12, 412-424.

HSU, P.-F. 2013b. Integrating ERP and e-business: Resource complementarity in business value creation. Decision Support Systems, 56, 334-347.

HUANG, T. \& YASUDA, K. 2016. Comprehensive review of literature survey articles on ERP. Business Process Management Journal, 22, 2-32.

HWANG, Y. 2005. Investigating enterprise systems adoption: uncertainty avoidance, intrinsic motivation, and the technology acceptance model. European journal of information systems, 14, 150161.

IRIANA, R. \& BUTTLE, F. 2006. Strategic, Operational, and Analytical Customer Relationship Management: Attributes and Measures. Journal of Relationship Marketing, 5, 23-34.

JAYACHANDRAN, S., SHARMA, S., KAUFMAN, P. \& RAMAN, P. 2005. The role of relational information processes and technology use in customer relationship management. Journal of Marketing, 69, 177-192.

KARIMI, J., SOMERS, T. M. \& GUPTA, Y. P. 2001. Impact of information technology management practices on customer service. Journal of Management Information Systems, 17, 125-158.

KIM, C., LEE, I.-S., WANG, T. \& MIRUSMONOV, M. 2015. Evaluating effects of mobile CRM on employees' performance. Industrial Management \& Data Systems, 115, 740-764.

KING, F. S. \& BURGESS, F. T. 2008. Understanding success and failure in customer relationship management. Industrial Marketing Management, 37, 421-431.

LAFRAMBOISE, K. \& REYES, F. 2005. Gaining competitive advantage from integrating enterprise resource planning and total quality management. Journal of Supply Chain Management, 41, 49-64.

LEIDNER, D. E. \& KAYWORTH, T. 2006. A review of culture in information systems research: toward a theory of information technology culture conflict. MIS Quarterly, 30, 357-399.

LIGHT, B. 2003. CRM packaged software: a study of organisational experiences. Business Process Management Journal, 9, 603-616.

LIU, A. Z., LIU, H. \& XU, S. X. 2013. How do competitive environments moderate CRM value? Decision Support Systems, 56, 462-473.

MABERT, V. A., SONI, A. \& VENKATARAMANAN, M. A. 2003. The impact of organization size on enterprise resource planning (ERP) implementations in the US manufacturing sector. The International Journal of Management Science, 31, 235-246.

MAY, J., DHILLON, G. \& CALDEIRA, M. 2013. Defining Value-based Objectives for ERP Systems Planning. Decision Support Systems, 55, 98-109.

MELVILLE, N., KRAEMER, K. L. \& GURBAXANI, V. 2004. Information technology and organizational performance: an integrative model of IT business value. MIS Quarterly, 28, 283-322.

MINAMI, C. \& DAWSON, J. 2008. The CRM process in retail and service sector firms in Japan: Loyalty development and financial return. Journal of Retailing and Consumer Services, 15, 375-385.

MISHRA, A. N. \& AGARWAL, R. 2010. Technological frames, organizational capabilities, and IT use: an empirical investigation of electronic procurement. Information Systems Research, 21, 249-270.

MITHAS, S., KRISHNAN, M. S. \& FORNELL, C. 2005. Why do customer relationship management applications affect customer satisfaction? Journal of Marketing, 69, 201-209.

MITHAS, S., RAMASUBBU, N. \& SAMBAMURTHY, V. 2011. How Information Management Capability Influences Firm Performance. MIS Quarterly, 35, 237-256.

NARAYANAN, S., JAYARAMAN, V., LUO, Y. \& SWAMINATHAN, J. M. 2011. The antecedents of process integration in business process outsourcing and its effect on firm performance. Journal of Operations Management, 29, 3-16.

NGAI, E. W. 2005. Customer relationship management research (1992-2002) An academic literature review and classification. Marketing intelligence \& planning, 23, 582-605.

NGAI, E. W., XIU, L. \& CHAU, D. C. 2009. Application of data mining techniques in customer relationship management: A literature review and classification. Expert systems with applications, 36, 2592-2602.

NGUYEN, B. \& MUTUM, D. S. 2012. A review of customer relationship management: successes, advances, pitfalls and futures. Business Process Management Journal, 18, 400-419.

NICOLAOU, A. I. 2004. Firm Performance Effects in Relation to the Implementation and Use of Enterprise Resource Planning Systems. Journal of Information Systems, 18, 79-105.

NICOLAOU, A. I. \& BHATTACHARYA, S. 2006. Organizational Performance Effects of ERP Systems 
Usage: The Impact of Post-Implementation Changes. International Journal of Accounting Information Systems, 7, 18-35.

NICOLAOU, A. I. \& BHATTACHARYA, S. 2008. Sustainability of ERPs performance outcomes: the role of post-implementation review quality. International Journal of Accounting Information Systems, 9, 43-60.

OSARENKHOE, A. \& BENNANI, A.-E. 2007. An exploratory study of implementation of customer relationship management strategy. Business Process Management Journal, 13, 139-164.

PADMANABHAN, B., ZHENG, Z. \& KIMBROUGH, S. O. 2006. An empirical analysis of the value of complete information for eCRM models. MIS Quarterly, 247-267.

PAULISSEN, K., MILIS, K., BRENGMAN, M., FJERMESTAD, J. \& ROMANO JR, N. C. Voids in the current CRM Literature: Academic literature review and classification (2000-2005). System Sciences, 2007. HICSS 2007. 40th Annual Hawaii International Conference on, 2007. IEEE, 150c-150c.

PAYNE, A. \& FROW, P. 2005. A strategic Framework for Customer Relationship Management. Journal of Marketing, 69, 167-176.

PAYNE, A. \& FROW, P. 2006. Customer Relationship Management: from Strategy to Implementation. Journal of Marketing Management, 22, 135-168.

PEDRON, C. D., PICOTO, W. N., DHILLON, G. \& CALDEIRA, M. 2016. Value-focused objectives for CRM system adoption. Industrial Management \& Data Systems, 116, 526-545.

PICOTO, W. N., BÉLANGER, F. \& PALMA-DOS-REIS, A. 2014. An organizational perspective on mbusiness: usage factors and value determination. European Journal of Information Systems, 23, 571592.

PODSAKOFF, P., MACKENZIE, S., LEE, J. \& PODSAKOFF, N. 2003. Common method biases in behavioral research: a critical review of the literature and recommended remedies. The Journal of Applied Psychology, 88, 879-903.

RAI, A., PATNAYAKUNI, R. \& SETH, N. 2006. Firm performance impact of digitally-enabled supply chain integration capabilities. MIS Quarterly, 30, 225-246.

RAM, J., CORKINDALE, D. \& WU, M.-L. 2013. Examining the role of system quality in ERP projects. Industrial Management \& Data Systems, 113, 350-366.

RAM, J., CORKINDALE, D. \& WUC, M.-L. 2014. ERP adoption and the value creation: Examining the contributions of antecedents. Journal of Engineering and Technology Management, 33, 113-133.

RANGANATHAN, C. \& BROWN, C. 2006. ERP investments and the market value of firms: toward an understanding of influential ERP project variables. Information Systems Research, 2, 145-161.

REINARTZ, W., KRAFFT, M. \& HOYER, W. D. 2004. The customer relationship management process: its measurement and impact on performance. Journal of Marketing Research, 41, 293-305.

RHODES, J., LOK, P., YANG, S. \& BAMBACAS, M. 2009. Resource-based view of intangibles on ERP systems implementation and organizational performance in China. Journal of Global Strategic Management, 5, 87-96.

RINGLE, C. M., WENDE, S. \& WILL, A. 2005. SmartPLS 2.0, Ringle.

ROH, J. J. \& HONG, P. 2015. Taxonomy of ERP integrations and performance outcomes: an exploratory study of manufacturing firms. Production Planning \& Control, 26, 617-636.

ROMANO JR, N. C. \& FJERMESTAD, J. 2003. Electronic commerce customer relationship management: A research agenda. Information Technology and Management, 4, 233-258.

RUIVO, P., OLIVEIRA, T. \& NETO, M. 2012. ERP use and value: Portuguese and Spanish SMEs. Industrial Management \& Data Systems, 112, 1008-1025.

RUIVO, P., OLIVEIRA, T. \& NETO, M. 2015. Using resource-based view theory to assess the value of ERP commercial-packages in SMEs. Computers in Industry, 13, 105-116.

RYALS, L. 2005. Making Customer Relationship Management Work: The Measurement and Profitable Management of Customer Relationships. Journal of Marketing, 69, 252-272.

RYANS, A. B. 1974. Estimating consumer preferences for a new durable brand in an established product class. Journal of Marketing Research, 434-443.

SAMARANAYAKE, P. 2009. Business process integration, automation, and optimization in ERP: integrated approach using enhanced process models. Business Process Management Journal, 15, 504526.

SCHLICHTER, B. R. \& KRAEMMERGAARD, P. 2010. A comprehensive literature review of the ERP research field over a decade. Journal of Enterprise Information Management, 23, 486-520.

SHEHAB, E., SHARP, M., SUPRAMANIAM, L. \& SPEDDING, T. A. 2004. Enterprise resource planning: An integrative review. Business Process Management Journal, 10, 359-386.

SOLTANI, Z. \& NAVIMIPOUR, N. J. 2016. Customer relationship management mechanisms: A systematic review of the state of the art literature and recommendations for future research. Computers in Human Behavior, 61, 667-688. 
UWIZEYEMUNGU, S. \& RAYMOND, L. 2012. Impact of an ERP system's capabilities upon the realisation of its business value: a resource-based perspective. Information Technology and Management, 13, 69-90.

VELCU, O. 2007. Exploring the effects of ERP systems on organizational performance: evidence from Finnish companies. Industrial Management \& Data Systems, 107, 1316-1334.

VENKATESH, V., THONG, J. Y. L. \& XU, X. 2012. Consumer acceptance and use of information technology: extending the unified theory of acceptance and use of technology. MIS Quarterly, 36, 157-178.

WADE, M. \& HULLAND, J. 2004. The resource-based view and information systems research: review, extension, and suggestions for future research. MIS Quarterly, 28, 107-142.

WAHLBERG, O., STRANDBERG, C. \& SANDBERG, K. W. 2009. Trends, topics and underresearched areas in CRM research - a literature review. International Journal of Public Information Systems, 5.

WILLIS, T. \& WILLIS-BROWN, A. 2002. Extending the value of ERP. Industrial Management \& Data Systems, 102, 35-38.

ZHANG, Z., LEE, M. K. O., HUANG, P., ZHANG, L. \& HUANG, X. 2005. A framework of ERP systems implementation success in China: An empirical study. International Journal of Production Economics, 98, 56-80.

ZHU, K. \& KRAEMER, K. L. 2005. Post-adoption variations in usage and value of e-business by organizations: Cross-country evidence from the retail industry. Information Systems Research, 16, 6184.

\section{Appendix - Item measurements}




\section{Figures of article file}

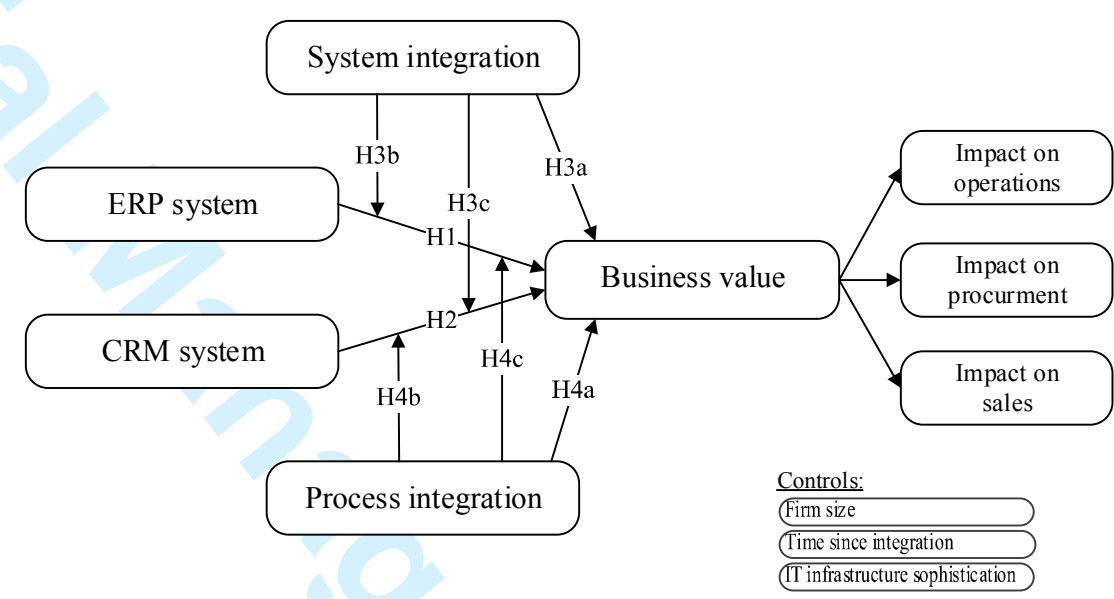

Figure 1. Research model to assess the impact of ERP and CRM value on business value

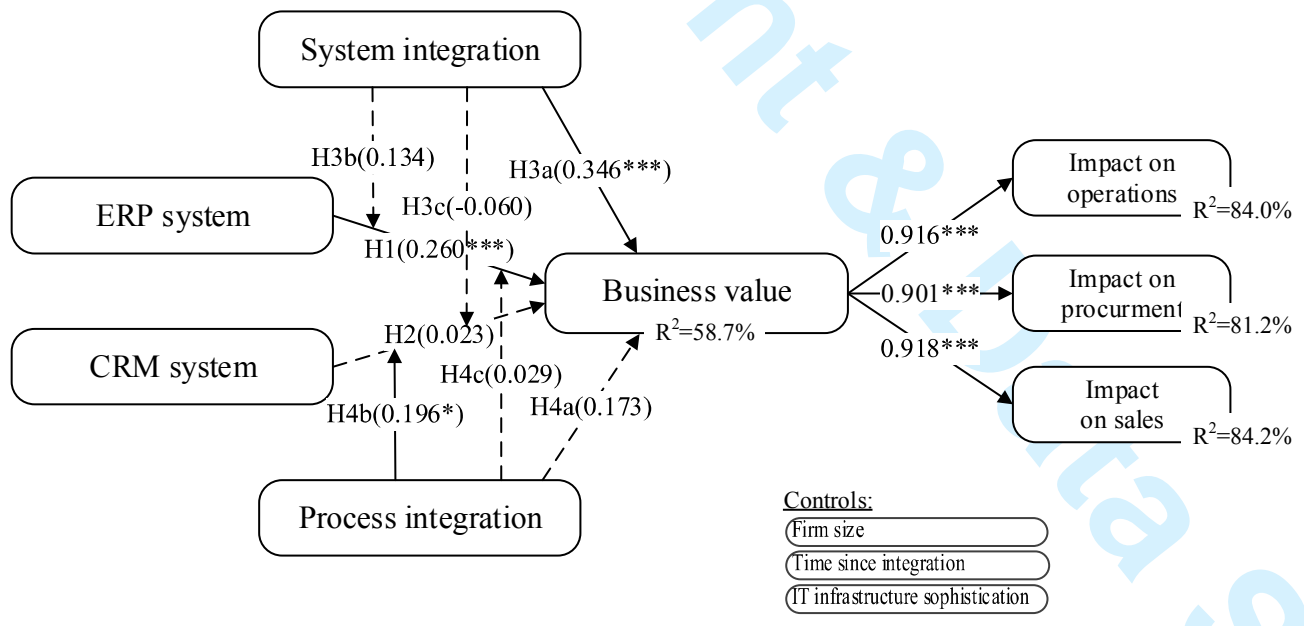

${ }^{*} \mathrm{p}<0.10 ; * * \mathrm{p}<0.05 ;{ }^{* * *} \mathrm{p}<0.01$. To avoid a crowded graph, indicators for each construct are not shown in the graph.

Figure 2. Model results and path coefficients. 


\section{Tables of article file}

\begin{tabular}{|c|c|c|c|}
\hline \multicolumn{2}{|l|}{ Characteristics } & \multirow{2}{*}{$\begin{array}{l}(\mathbf{N}) \\
64\end{array}$} & \multirow{3}{*}{$\begin{array}{l}\mathbf{( \% )} \\
51.2 \\
48.8\end{array}$} \\
\hline & Spain & & \\
\hline Country & Portugal & 61 & \\
\hline \multirow{6}{*}{ Industry type } & Professional services & 40 & 32.0 \\
\hline & Retail & 31 & 24.8 \\
\hline & Manufacturing & 23 & 18.4 \\
\hline & Financial services & 17 & 13.6 \\
\hline & Information technology & 8 & 6.4 \\
\hline & Utilities & 6 & 4.8 \\
\hline \multirow{6}{*}{$\begin{array}{l}\text { Respondent's } \\
\text { role }\end{array}$} & IT/IS manager & 32 & 25.6 \\
\hline & $\mathrm{CEO}$ /owner & 30 & 24.0 \\
\hline & Sales manager & 29 & 23.2 \\
\hline & Manufacturing manager & 13 & 10.4 \\
\hline & Logistics manager & 11 & 8.8 \\
\hline & Finance manager & 10 & 8.0 \\
\hline \multirow{5}{*}{$\begin{array}{l}\text { Annual } \\
\text { Turnover (€) }\end{array}$} & $<1 \mathrm{M}$ & 20 & 16.0 \\
\hline & $1 \mathrm{M}$ to $10 \mathrm{M}$ & 47 & 37.6 \\
\hline & $10 \mathrm{M}$ to $25 \mathrm{M}$ & 28 & 22.4 \\
\hline & $25 \mathrm{M}$ to $50 \mathrm{M}$ & 18 & 14.4 \\
\hline & $>50 \mathrm{M}$ & 12 & 9,60 \\
\hline \multirow{4}{*}{ Firm size } & $<49$ & 31 & 24.8 \\
\hline & 50 to 99 & 28 & 22.4 \\
\hline & 100 to 249 & 39 & 31.2 \\
\hline & $>250$ & 27 & 21.6 \\
\hline \multirow{5}{*}{$\begin{array}{l}\text { Years since } \\
\text { integration }\end{array}$} & $<1$ & 12 & 9,6 \\
\hline & 1 to 2 & 27 & 22,4 \\
\hline & 3 to 5 & 75 & 56,8 \\
\hline & 6 to 10 & 11 & 8,8 \\
\hline & $>10$ & 3 & $\begin{array}{l}0,0 \\
2,4\end{array}$ \\
\hline \multirow{10}{*}{ ERP system } & Microsoft & 46 & 36.8 \\
\hline & SAP & 30 & 24.0 \\
\hline & Oracle & 13 & 10.4 \\
\hline & Primavera & 9 & 7.2 \\
\hline & PHC & 8 & 6.4 \\
\hline & Sage & 8 & 6.4 \\
\hline & PeopleSoft & 3 & 2.4 \\
\hline & OutSystems & 2 & 1.6 \\
\hline & ArtSoft & 2 & 1.6 \\
\hline & Others & 4 & 3.2 \\
\hline \multirow{10}{*}{ CRM system } & Microsoft & 56 & 44,8 \\
\hline & Salesforce & 26 & 20,8 \\
\hline & Custom made & 11 & 8,8 \\
\hline & NetSuite & 7 & 5,6 \\
\hline & Oracle & 2 & 1,6 \\
\hline & Sage & 7 & 5,6 \\
\hline & SAP & 6 & 4,8 \\
\hline & Primavera & 3 & 2,4 \\
\hline & Zoho & 5 & 4.0 \\
\hline & Others & 2 & 1,6 \\
\hline \multirow{3}{*}{$\begin{array}{l}\text { IT infrastructure } \\
\text { sophistication }\end{array}$} & IT architecture and standards & 111 & 88.8 \\
\hline & Security and risk management policies & 99 & 79.2 \\
\hline & The latest back-end technology & 87 & 69.6 \\
\hline
\end{tabular}

Notes: N-number of responses; \%-the percentage of the 125 respondents.

Table 1. Characteristics of the sample. 


\begin{tabular}{|c|c|c|c|c|c|c|}
\hline Variable & & Items & Loading & t-Stat* & AVE & CR \\
\hline \multirow{3}{*}{\multicolumn{2}{|c|}{ CRM system }} & CRM1 & 0.717 & 10.158 & \multirow{3}{*}{0.517} & \multirow{3}{*}{0.760} \\
\hline & & CRM2 & 0.628 & 7.151 & & \\
\hline & & CRM3 & 0.800 & 12.444 & & \\
\hline \multirow{2}{*}{\multicolumn{2}{|c|}{ ERP system }} & ERP1 & 0.684 & 7.854 & \multirow{2}{*}{0.628} & \multirow{2}{*}{0.769} \\
\hline & & ERP2 & 0.888 & 19.493 & & \\
\hline \multirow{3}{*}{\multicolumn{2}{|c|}{ System integration }} & SYI1 & 0.887 & 36.709 & \multirow{3}{*}{0.628} & \multirow{3}{*}{0.769} \\
\hline & & SYI2 & 0.890 & 31.019 & & \\
\hline & & SYI3 & 0.717 & 10.754 & & \\
\hline \multirow{3}{*}{\multicolumn{2}{|c|}{ Process integration }} & PRI1 & 0.846 & 28.264 & \multirow{3}{*}{0.696} & \multirow{3}{*}{0.873} \\
\hline & & PRI2 & 0.817 & 19.600 & & \\
\hline & & PRI3 & 0.839 & 18.013 & & \\
\hline \multirow{6}{*}{$\begin{array}{l}\text { Business value } \\
\left(2^{\text {nd }} \text { order }\right. \\
\text { construct })\end{array}$} & \multirow{2}{*}{$\begin{array}{l}\text { Impact on } \\
\text { operations }\end{array}$} & IO1 & 0.870 & 44.526 & \multirow{2}{*}{0.764} & \multirow{2}{*}{0.866} \\
\hline & & $\mathrm{IO} 2$ & 0.878 & 44.006 & & \\
\hline & \multirow{2}{*}{$\begin{array}{l}\text { Impact on } \\
\text { procurement }\end{array}$} & IP1 & 0.889 & 47.255 & \multirow{2}{*}{0.752} & \multirow{2}{*}{0.858} \\
\hline & & IP2 & 0.845 & 21.596 & & \\
\hline & \multirow{2}{*}{$\begin{array}{l}\text { Impact on } \\
\text { sales }\end{array}$} & IS1 & 0.926 & 67.193 & \multirow{2}{*}{0.849} & \multirow{2}{*}{0.918} \\
\hline & & IS2 & 0.917 & 52.539 & & \\
\hline
\end{tabular}

Table 2. Item question loadings, $\mathrm{CR}$, and AVE variables values

\begin{tabular}{l|c|c|c|c|c|c|c|c|c|c}
\hline \multicolumn{1}{c|}{ Variable } & Mean & SD & CRM & ERP & SYI & PRI & VAL & IO & IP & IS \\
\hline CRM system (CRM) & 3.536 & 0.939 & $\mathbf{0 . 7 1 9}$ & & & & & & & \\
\hline ERP system (ERP) & 3.664 & 1.107 & 0.659 & $\mathbf{0 . 7 9 3}$ & & & & & & \\
\hline System integration (SYI) & 3.299 & 1.191 & 0.590 & 0.573 & $\mathbf{0 . 8 3 5}$ & & & & & \\
\hline Process integration (PRI) & 3.093 & 1.130 & 0.573 & 0.519 & 0.705 & $\mathbf{0 . 8 3 4}$ & & & & \\
\hline Integrative value (VAL) & 3.568 & 0.933 & 0.536 & 0.573 & 0.654 & 0.621 & $\mathbf{0 . 8 0 9}$ & & & \\
\hline Impact on operations (IO) & 3.656 & 0.954 & 0.505 & 0.501 & 0.599 & 0.596 & 0.916 & $\mathbf{0 . 8 7 4}$ & & \\
\hline Impact on procurement (IP) & 3.577 & 0.926 & 0.490 & 0.563 & 0.603 & 0.533 & 0.901 & 0.749 & $\mathbf{0 . 8 6 7}$ & \\
\hline Impact on sales (IS) & 3.452 & 1.219 & 0.472 & 0.506 & 0.588 & 0.569 & 0.918 & 0.764 & 0.729 & $\mathbf{0 . 9 2 1}$ \\
\hline
\end{tabular}

Table 3. Descriptive statistics, correlations, and the square root of AVEs. 


\section{Appendix - Item measurements}

\begin{tabular}{|c|c|c|c|}
\hline \multicolumn{3}{|c|}{ Variable $\quad$ Indicators } & $\begin{array}{l}\text { Literature } \\
\text { support }\end{array}$ \\
\hline \multicolumn{4}{|c|}{ Taking into consideration the integration of ERP with CRM please rate the following questions: } \\
\hline \multicolumn{2}{|c|}{ ERP system } & $\begin{array}{l}\text { Using a five-point scale, where } 1 \text { means 'low' and } 5 \text { 'high', please rate to the } \\
\text { extent to which: } \\
\text { ERP1 - your firm uses Financial module } \\
\text { ERP2 - your firm uses Supply chain module } \\
\text { ERP3 - your firm uses Manufacturing module }\end{array}$ & $\begin{array}{l}\text { (Ranganathan } \\
\text { and Brown, } \\
\text { 2006) }\end{array}$ \\
\hline \multicolumn{2}{|c|}{ CRM system } & $\begin{array}{l}\text { Using a five-point scale, where } 1 \text { means 'low' and } 5 \text { 'high', please rate the } \\
\text { extent to which: } \\
\text { CRM1 - your firm uses Sales module } \\
\text { CRM2 - your firm uses Marketing module } \\
\text { CRM3 - your firm uses Service module }\end{array}$ & $\begin{array}{l}\text { (Payne and } \\
\text { Frow, 2005) }\end{array}$ \\
\hline \multicolumn{2}{|c|}{ System Integration } & $\begin{array}{l}\text { Using a five-point scale, where } 1 \text { means 'low' and } 5 \text { 'high', please rate the } \\
\text { extent to which: } \\
\text { SYI1 - your ERP is integrated with your CRM system } \\
\text { SYI2 - your ERP system is integrated with your business partner's IS } \\
\text { SYI3 - your CRM is accessible by your business partner via web or other } \\
\text { electronic networks }\end{array}$ & $\begin{array}{l}\text { (Barki and } \\
\text { Pinsonneault, } \\
\text { 2005) }\end{array}$ \\
\hline \multicolumn{2}{|c|}{ Process Integration } & $\begin{array}{l}\text { Using a five-point scale, where } 1 \text { means 'low' and } 5 \text { 'high', please rate the } \\
\text { extent to which: } \\
\text { PRI1 - your firm shares inventory levels across departments or locations } \\
\text { PRI2 - your firm shares product information across departments or locations } \\
\text { PRI3 - your firm shares demand and forecasting information across } \\
\text { departments or locations }\end{array}$ & $\begin{array}{l}\text { (Rai et al., } \\
\text { 2006) }\end{array}$ \\
\hline \multirow{4}{*}{ 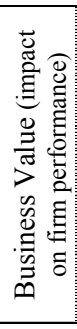 } & \multirow{5}{*}{$\begin{array}{l}\text { Impact on } \\
\text { operations } \\
\text { Impact on } \\
\text { procurement } \\
\text { Impact on } \\
\text { sales } \\
\end{array}$} & $\begin{array}{l}\text { Using a five-point scale, where } 1 \text { means" increased a lot" and 5-"decreased a } \\
\text { lot", please rate the extent to which the following have increased, decreased, or } \\
\text { stayed the same in your firm as a result of using integration of ERP with CRM: }\end{array}$ & \multirow{4}{*}{$\begin{array}{l}\text { (Zhu and } \\
\text { Kraemer, } \\
\text { 2005) }\end{array}$} \\
\hline & & $\begin{array}{l}\text { IO1 - Internal operations costs } \\
\text { IO2 - On time delivery }\end{array}$ & \\
\hline & & $\begin{array}{l}\text { IP1 - Procurement costs } \\
\text { IP2 - Inventory costs }\end{array}$ & \\
\hline & & $\begin{array}{l}\text { IS1 - Sales } \\
\text { IS2 - Customer service and support }\end{array}$ & \\
\hline \multicolumn{3}{|c|}{ (3) } & \\
\hline & & $\begin{array}{l}\text { Please assess your firm's IT infrastructure sophistication }(\mathrm{Y} / \mathrm{N}) \text { : } \\
\text { ITAS - IT architecture and standards } \\
\text { SRMP - Security and risk management policies } \\
\text { LBET - The latest back-end technology }\end{array}$ & $\begin{array}{l}\text { (Elbashir et al., } \\
\text { 2013) }\end{array}$ \\
\hline
\end{tabular}

43

44

45

46

47

48

49

50

51

52

53

54

55

56 


\section{Enterprise Resource Planning and Customer Relationship Management Value Manuscript ID: IMDS-08-2016-0340.R1}

\section{Reviewer 1:}

\section{Reviewer:}

Comments:

It is suggested that the paper be proofread again, after making minor corrections as required.

Authors comment: The authors re-worked the paper with a native English professional proofreader.

\section{Reviewer:}

Additional Questions:

$<\mathrm{b}>1$. Originality: $</ \mathrm{b}>$ Does the paper contain new and significant information adequate to justify publication?: Yes

Authors comment: The authors are grateful for the reviewer's acknowledgment that the paper is adequate to justify publication.

\section{Reviewer:}

$<\mathrm{b}>2$. Relationship to Literature: $</ \mathrm{b}>$ Does the paper demonstrate an adequate understanding of the relevant literature in the field and cite an appropriate range of literature sources? Is any significant work ignored?: Yes, the paper demonstrates an adequate undertanding of relevant literature in the field.

Authors comment: The authors are grateful for the reviewer's acknowledgment that the paper demonstrates an adequate understanding of relevant literature in the field.

\section{Reviewer:}

$<b>3$. Methodology: $</ b>$ Is the paper's argument built on an appropriate base of theory, concepts, or other ideas? Has the research or equivalent intellectual work on which the paper is based been well designed? Are the methods employed appropriate?: Research methodology is relevant and appropriate.

Authors comment: The authors are grateful for the reviewer's acknowledgment that the paper's methodology is relevant and appropriate.

\section{Reviewer:}

$<\mathrm{b}>4$. Results: $</ \mathrm{b}>$ Are results presented clearly and analysed appropriately? Do the conclusions adequately tie together the other elements of the paper?: Overall presentation is improved.

Authors comment: The authors are grateful for the reviewer's acknowledgment of the overall results presentation improvement.

\section{Reviewer:}

$<b>5$. Implications for research, practice and/or society $</ b>$ Does the paper identify clearly between any implications for research, practice and/or society? Does the paper bridge the gap between theory and practice? How can the research be used in practice (economic and commercial impact), in teaching, to influence public policy, in research (contributing to the body of knowledge)? What is the impact upon society (influencing public attitudes, affecting quality of life)? Are these implications consistent with the findings and conclusions of the 
paper?: All are improved. However, one of the fundamental aspects not covered in the managerial implication is level of integration and its association with ERP and CRM systems, when impacting on the business value.

Authors comment: The authors acknowledge the reviewer's claim and enhance the first and third implications to managers in subsection "6.3. Managerial implication":

"We make four fundamental managerial recommendations with this study: i) Firstly, the results imply that firms can create business value by developing a joint software system consisting of ERP and CRM. More precisely, results show that firms with greater levels of system integration are generating higher business value. This implies that managers should define as a strategy the integration of disconnected systems such as CRM and ERP to achieve higher value. This points to the importance of moving beyond individual systems value creation. ii) Secondly, our results showing the significant value implication of ERP on business value but not significant for CRM, imply that ERP systems per se create higher business value even when coupled with a CRM system. This implies that managers should first focus on making sure that the firm's ERP systems are well implemented and configured and then couple CRM and other systems. In doing this, the value of ERP is amplified (Hsu, 2013b, Pedron et al., 2016). iii) Thirdly, our results show that when CRM and ERP are simply technically integrated, CRM does not create high business value. CRM creates greater business value when processes are integrated with ERP and other systems. This points to the importance of broader IT system integration when coupling systems. Instead of accumulating functional modules within a software system and having the systems technically integrated, both IT and functional managers need to take into consideration processes integration between systems. Managers should blur the lines between CRM and ERP systems by also pushing ERP information to the frontline CRM, shifting from unidirectional to bidirectional data-flow between systems. If firm's sales, service, and other frontline departments have fingertip access to select ERP information in their CRM system, they can immediately address customer questions about product availability or review the status of credit checks for new customers without wasting time emailing or chasing their finance team.”

\section{Reviewer:}

$<\mathrm{b}>6$. Quality of Communication: $</ \mathrm{b}>$ Does the paper clearly express its case, measured against the technical language of the field and the expected knowledge of the journal's readership? Has attention been paid to the clarity of expression and readability, such as sentence structure, jargon use, acronyms, etc.: Improved. However, there are still some issues associated with communication. For example, "Adopting a CRM system calls for Process integration" as part of practical implications does not seem to provide a clear message and not connected with the content presented in the body.

Authors comment: The authors acknowledge the reviewer's concerns and we went through the paper to address the issues associated with communication. We also reworked the statement in accordance with the content presented in the paper's body:

Practical implications - Adopting an ERP system and ensuring System integration provides a direct impact on business value. Adopting a CRM system calls for Process integration. In order for a CRM system to have a positive impact on business value, Process integration with ERP system must be ensured. 


\begin{abstract}
Reviewer 2:
Reviewer:

Comments:

1. The quality of literature review has been improved. After the redesign, the literature review section is comprehensive with a clear structure and includes more relevant literature. It now focuses on the value of ERP system and CRM system and the integration of two systems. With these improvement, this section is logically designed and provides a good theoretical background.
\end{abstract}

Authors comment: The authors are grateful for the reviewer's acknowledgment of the literature review's section improvement.

\title{
Reviewer:
}

2. The data section is now stated more clearly. However, some discussion is still not strong enough. For example, the authors stated that they chose companies from Portugal and Spain because they are the countries with the highest uncertainty, but it does not convince me that this study can stand for firms in different areas and from different countries.

Authors comment: The authors are grateful for the reviewer's acknowledgment that the data section is clearer. Furthermore, the authors acknowledge the reviewer's concerns about choosing Portugal and Spain for testing the model, and added a statement into the subsection "4.1. Data":

"In accordance with Hwang (2005), a socio-technical approach of enterprise systems involves the integration of business process and technical aspects such as systems integration to overcome uncertainty. Moreover, Hofstede's (2001) cultural dimensions study concluded that Portugal and Spain (composing the Iberian region) are the countries with the highest uncertainty avoidance rate. We therefore selected these two countries as a proxy (Leidner and Kayworth, 2006).

It should be noted that the goal of studying these two countries was to understand the relationships of the proposed model. Careful attention was given to ensure the validity and reliability of the findings. That is, the sample was carefully and systematically identified; primary data were used; pilot-test was developed prior to the web-survey; data were stratified by industry area and firm size, and collected and stored in a systematic manner; and the results were revised, verified, and analysed with advanced statistics (Zhu and Kraemer, 2005). Our future research will be to test the model for firms in different areas and from different countries. It should be noted that the goal of studying these two countries was to understand the relationships of the proposed model. Careful attention was given to ensure the validity and reliability of the findings. That is, the sample was carefully and systematically identified; primary data were used; pilot-test was developed prior to the web-survey; data were stratified by industry area and firm size, and collected and stored in a systematic manner; and the results were revised, verified, and analysed with advanced statistics (Zhu and Kraemer, 2005). Our future research will be to test the model for firms in different areas and from different countries."

The authors have reinforced this concern in subsection "6.3. Limitations and future work":

"One of the limitations of our research has to do with the sample size and variety. We targeted 400 firms in Portugal and Spain with the questionnaire and received 125 valid responses. Future work might will be to assess the model's variables relationships based on having with a larger sample by, for example, expanding it to other countries and comparing the results."

Note that the Iberia region is composed of Portugal and Spain. As an economic marketplace, this region is considered as one, with the strongest commercial relationships with Latin America and Africa countries. Moreover, the great majority of firm's centre their operations in one country in the region - usually in Madrid (Spain) or Lisbon (Portugal) (Maria García, 2015).

García, María. "The European Union and Latin America: 'Transformative power Europe' versus the realities of economic interests." Cambridge Review of International Affairs 28.4 (2015): 621-640.

Zhu, Kevin, and Kenneth L. Kraemer. "Post-adoption variations in usage and value of e-business by organizations: cross-country evidence from the retail industry." Information systems research 16.1 (2005): 61-84.

\section{Reviewer:}


3. In section 5.1, the authors add explanations of the statistical concepts used. However, the question why we should test indicator reliability remains unanswered.

\title{
Authors comment:
}

Based on Hair et al (2016, page 319) "Indicator reliability: is the square of a standardized indicator's outer loading. It represents how much of the variation in an item is explained by the construct and is referred to as the variance extracted from the item". In the context of partial least squares (PLS) the indicator reliability is one of the measures that allow for the evaluation of the measurement model for the reflective constructs (Hair et al., 2016, Henseler et at., 2009). As in our model we have reflective constructs, we test indicator reliability to evaluate the measurement model.

The authors have added the explanation why the indicator reliability was tested in section "5.1.Measurement model":

\begin{abstract}
"In our model we have reflective constructs. In the context of PLS the measurement model for the reflective constructs should be evaluated based on assessed indicator reliability, construct reliability, convergent validity, and discriminant validity (Henseler et al., 2009). 1) The indicator reliability is the absolute standardized loadings. This indicator was evaluated based on the criteria that the loadings should be greater than 0.7 and that every loading less than 0.4 should be eliminated (Churchill, 1979, Henseler et al., 2009). The items are reported in Table 2, where it is seen that the loadings are greater than 0.7 , with the exception of two (CRM2 and ERP1), which are lower than 0.7 but greater than 0.4 . Hence, no items in the table were eliminated. All the items are statistically significant at 0.001 . Overall, the instrument presents good indicator reliability."
\end{abstract}

Hair Jr, J. F., Hult, G. T. M., Ringle, C., \& Sarstedt, M. (2016). A primer on partial least squares structural equation modeling (PLS-SEM): Sage Publications.

Henseler, J., Ringle, C. M., \& Sinkovics, R. R. (2009). The use of partial least squares path modeling in international marketing. In R. R. Sinkovics \& P. N. Ghauri (Eds.), New Challenges to International Marketing (Vol. 20, pp. 277-319). Stamford: Jai Press Inc.

\section{Reviewer:}

4. Practical implication is demonstrated more in detail and shows importance of the research to managerial aspect. But I cannot quite understand the fourth recommendation. According to the results, if CRM vendors want to develop their applications to create higher value, they should do it through process integration. Whether "social networks and sentiment analysis systems" is part of process integration needs to be stated clearly, to make readers understand it with ease.

Authors comment: The authors are grateful for the reviewer's acknowledgment of the practical implication subsection's improvement. We acknowledge the reviewer's concerns and reworked the fourth recommendation in order for readers to easily understand, in subsection "6.1. Managerial implication":

\begin{abstract}
“iv) Lastly, CRM vendors should pay attention to developing their applications to create higher value in accordance with business process integration, for example, social networks and sentiment analysis systems as part of CRM process integration. This may help increase the value of customer's CRM systems, the joint value of CRM and ERP, as well as and the market value of vendor's products."
\end{abstract}

\section{Reviewer:}

5. Overall, though the paper is improved, some issues need to be rewritten for better understanding. The authors should pay special attention to the discussion of sample selection, statistical concepts and practical implication.

Authors comment: The authors thank the reviewer for his remarks made in previous comments, which we believe have helped a great deal. In particular, comment $\# 2$ improved the discussion of sample selection. Comment\#3 improved the statistical concepts about why indicator reliability should be tested, and Comment \#4 emphasized that business process integration is the important aspect for CRM vendors for take into consideration in adding new CRM functionalities. Moreover the authors have revisited the paper with the assistance of an 
English professional to address grammatical issues and rewritten some statements for better understanding.

\section{Reviewer:}

Additional Questions:

$<\mathrm{b}>1$. Originality: $</ \mathrm{b}>$ Does the paper contain new and significant information adequate to justify publication?: Yes

Authors comment: The authors are grateful for the reviewer's acknowledgment of the paper's originality that justifies publication in IMDS.

\section{Reviewer:}

$<b>2$. Relationship to Literature: $</ b>$ Does the paper demonstrate an adequate understanding of the relevant literature in the field and cite an appropriate range of literature sources? Is any significant work ignored?: No

Authors comment: Taking in line reviewer's comment \#1, the authors are grateful for the reviewer's acknowledgment that no significant work was ignored.

\section{Reviewer:}

$<b>3$. Methodology: $</ b>$ Is the paper's argument built on an appropriate base of theory, concepts, or other ideas? Has the research or equivalent intellectual work on which the paper is based been well designed? Are the methods employed appropriate?: Yes

Authors comment: The authors are grateful for the reviewer's acknowledgment that the research methodology is relevant and appropriate.

\section{Reviewer:}

$<$ b $>4$. Results: $</$ b $>$ Are results presented clearly and analysed appropriately? Do the conclusions adequately tie together the other elements of the paper?: No

Authors comment: The authors are convinced that with the changes made in the managerial implication subsection (6.3), the results are clearly presented and better tied with the present study body. Please see manuscript.

\section{Reviewer:}

$<\mathrm{b}>5$. Implications for research, practice and/or society $</ \mathrm{b}>$ Does the paper identify clearly between any implications for research, practice and/or society? Does the paper bridge the gap between theory and practice? How can the research be used in practice (economic and commercial impact), in teaching, to influence public policy, in research (contributing to the body of knowledge)? What is the impact upon society (influencing public attitudes, affecting quality of life)? Are these implications consistent with the findings and conclusions of the paper?: No

Authors comment: The authors recognize the reviewer's claim. Also in line with comment \#4, the authors have redesigned and enhanced the implication subsection.

\section{Reviewer:}

$<\mathrm{b}>6$. Quality of Communication: $</ \mathrm{b}>$ Does the paper clearly express its case, measured against the technical language of the field and the expected knowledge of the journal's readership? Has attention been paid to the clarity of expression and readability, such as sentence structure, jargon use, acronyms, etc.: Yes 
1

2

3

4

5

6

7

8

9

10

11

12

13

14

15

16

17

18

19

20

21

22

23

24

25

26

27

28

28
29

30

31

32

33

34

35

36

37

38

39

40

41

42

43

44

45

46

47

48

49

50

51

52

53

54

55

56

57

58

59

60

Authors comment: The authors are grateful for the reviewer's acknowledgment of the overall quality of communication improvements. 